\title{
National Climate Change Policies and Sustainable Water Management: Conflicts and Synergies
}

\author{
Jamie Pittock $^{1}$
}

\begin{abstract}
Even in the absence of climate change, freshwater ecosystems and the resources they provide for people are under great pressure because of increasing demand for water and declines in water quality. The imminent onset of climate change will exacerbate these impacts, placing even greater pressure on already stressed resources and regions. A plethora of national climate change policies have been adopted that emphasize structural adjustment in the energy sector and increasing carbon sinks. To date, most public debate on water has focused on the direct impacts of climate change on hydrology. However, there is growing evidence that climate change policies themselves may have substantial additional and negative impacts on freshwater resources and ecosystems and may thus result in maladaptation. To avoid such maladaptation, integrated, coordinated policy making is required. In this paper, national climate change policies from Australia, Brazil, China, the European Union (EU), India, Mexico, South Africa, Tanzania, and the United Kingdom are compared to: (i) identify where negative trade-offs exist between climate change policies and freshwater resources, (ii) analyze where institutions and structures exist to optimize integration among climate, water, and biodiversity policies, and (iii) provide a much needed overview from a broad selection of countries with a view to identifying further opportunities for theoretical exploration and testing. The synergies and conflicts among climate, energy, water, and environmental policies create additional challenges for governments to develop integrated policies to deliver multiple benefits. Success factors for better policy development identified in this assessment and synthesis include engagement of senior political leaders, cyclical policy development, multi-agency and stakeholder processes, and stronger accountability and enforcement measures.
\end{abstract}

Key Words: Adaptation; climate change; conservation; energy; governments; policies; rivers

\section{INTRODUCTION}

Sustaining freshwater ecosystem services and responding adequately to climate change are two of the greatest challenges facing society (Rockström et al. 2009, Millenium Ecosystem Assessment (MEA) 2005a). Looking through the lens of national climate change policies of nine governments, this research examines if and how governments consider conflicts and potential synergies with linked, nonclimate sectors in energy, water, and biodiversity conservation, and whether institutions are in place to manage such sectoral integration.

\section{The water and climate change problem}

Globally, freshwater resources and biodiversity are threatened by non-climate drivers, resulting in growing water scarcity and significant declines in populations of freshwater species (MEA 2005b). It is anticipated that climate change impacts will be most immediately felt through direct impacts on water resources, including changes in precipitation and runoff, more extreme events such as floods and droughts, and declines in water quality, including those resulting from more frequent algal blooms (Bates et al. 2008).

\footnotetext{
${ }^{1}$ Australian National University
} 
There are many ways that our societies can choose to respond to climate change, and much of the current debate focuses on mitigating greenhouse gas emissions, which in turn relies on technologies that consume a lot of water or have significant impact upon freshwater ecosystems, e.g., growing more crops for biofuels. In considering whether additional water use resulting from climate policies matters, the different types of water and their use in climate change response measures are summarized, before considering the institutional implications.

\section{Types of water and water use}

Water flows can be categorized as green water (or vapor) that is available and used through plant transpiration, and liquid or blue water (Rockström et al. 1999). Human water use involves withdrawal from the natural environment and consumption (transforming water or turning it to vapor); another portion may be returned to freshwater ecosystems in liquid form (World Water Assessment Programme (WWAP) 2009). Water use assessments usually focus on blue water (Rockström and Gordon 2001 ), of which around $70 \%$ of withdrawn water is used in irrigated agriculture, and 20\% in industrial and energy production (WWAP 2009). The increasing importance of green water in meeting world food demand (Rockström et al. 1999, Comprehensive Assessment of Water Management in Agriculture (CAoWMiA) 2007) is one indication that alternative uses of water may have serious consequences, highlighting the need for better conjunctive management of green and blue water, termed ecohydrological landscape management (Rockström and Gordon 2001).

A further consideration for managing the energywater nexus is whether water needs are met by increasing supply or reducing demand, including through increased water use productivity (Butler and Memon 2006, Pittock and Lankford 2010). Climate change is anticipated to increase demand for water use, to replace losses from greater evaporation, for use in cooling, and in energy supply (Bates et al. 2008, WWAP 2009). There is a relationship between water supply and treatment, and demand for energy (Reffold et al. 2008, Stillwell et al. 2011), so increasing supply of water may exacerbate greenhouse gas emissions. Furthermore, water-related natural disasters, such as droughts or floods, are expected to increase in frequency with climate change, which may exacerbate the impacts on water-dependent climate change response measures (Bates 2008, Pittock 2009a). These types of water and issues in water use need to be considered in crafting climate change policies for low-carbon energy generation, carbon sequestration, and adaptation.

\section{Energy generation}

Energy is the most significant sector to be adjusted in our attempts to respond to climate change, and most energy generation technologies use blue water (Inhaber 2004, Smart and Aspinall 2009). Large volumes of water can be withdrawn, used, and returned to the aquatic environment, often with reduced quality, such as in once-through cooling in thermoelectric power stations and in hydroelectric power generation. Smaller volumes of water may be consumed through evaporation in steam generation and cooling processes or from hydroelectric facilities (Hutson et al. 2004, Smart and Aspinall 2009). In the United States, for example, $39 \%$ of total freshwater withdrawals, including $52 \%$ of surface-water withdrawals are used in thermoelectric power generation, but this amounts to just over $2 \%$ of total water consumption (Hutson et al. 2004, Stillwell et al. 2011). Although energy generation is a modest consumer of water globally, an increase in consumption matters because energy generation is often concentrated in areas where water is already scarce, where electricity supply has been or is likely to be curtailed by water shortages, and where increased withdrawals for energy generation have been proposed at the expense of environmental objectives, including in Australia, France, and the United States (Hightower and Pierce 2008, Smart and Aspinall 2009, Newell et al. 2011, Stillwell et al. 2011). Global energy consumption is expected to grow by $50 \%$ by 2030 , thus increasing demand for water use in production and raising the stakes for scarce water resources (Hightower and Pierce 2008).

The water footprint of energy technologies varies considerably, and thus, policy makers have a range of options for managing the energy-water nexus. Fossil, nuclear, solar, and wind energy can be produced with relatively modest water supplies, but consumption in hydropower, geothermal, and bioenergy production is one to two orders of magnitude higher than this first group of technologies (Inhaber 2004, Gerbens-Leenes et al. 2008). Energy from biofuel production, for instance, has been promoted by governments in 
countries like China and India, where there are water shortages and the required green and blue water for biofuel crop production may not be available (de Fraiture et al. 2008). Furthermore, greater use of low-carbon energy-production technologies, including concentrated solar, geothermal, and wind technologies, are being considered for arid and semi-arid regions, such as in Australia (Smart and Aspinall 2009) and the United States (Johnson 2009).

Although it is technically possible to use less water in thermal energy systems through dry cooling technologies, this incurs energy-efficiency penalties. Dry cooling in solar thermal plants may reduce water consumption by $90 \%$ but is less energy efficient $(-1-8 \%)$ and incurs greater costs $(+2-$ $10 \%)$, particularly in hotter environments (Department of Energy (DoE) 2008, Johnson 2009). Furthermore, the intermittent nature of energy generation by solar and wind systems requires them to have energy storage and back-up systems, and the most widely deployed technology to date is hydropower, which has a large blue water footprint where evaporation is high (Inhaber 2004).

\section{Carbon sequestration}

Many carbon sequestration methods also use considerable volumes of blue and green water. For instance, in most situations, afforestation increases evapotranspiration and reduces inflows into aquifers and watercourses (Herron et al. 2002, Calder 2007, van Dijk and Keenan 2007), with consequences even in humid environments (Calder and Newson 1979). In another example, the added internal energy and cooling requirements for carbon capture and storage (CCS) technology may increase blue water consumption in CCS power plants by a quarter (National Energy Technology Laboratory (NETL) 2008, Johnson 2009, Smart and Aspinall 2009). Hence, policies that favor carbon sequestration technologies could substantially increase demand for water.

\section{Adaptation and water}

Water-related climate adaptation measures may include supply-side, infrastructure-based, hardpath solutions, in the form of more dams, water transfers, and flood levees. Alternatively, soft-path solutions, such as decentralized systems, demand management, and ecosystem-based measures, may meet many societal needs for water services with lower water consumption and fewer impacts on the environment (Gleick 2002, Kabat and Schaik 2003, Pittock 2009b).

Water is fully allocated in many regions (Falkenmark and Molden 2008), and demand for water by other users is increasing dramatically, especially in agriculture (CAoWMiA 2007). Therefore, even modest increases in water demand for energy production, carbon sequestration, and climate change adaptation are important because other human users and the environment will be affected. Other than for biofuels (de Fraiture et al. 2008), data are not yet available to assess quantitatively how much the full range of climate change and related policy priorities adopted by the governments increase water use or impact on freshwater ecosystems. Instead, this assessment examines national policies to identify the interplay between the sectors to discern whether conflicts or synergies have been recognized and to document the presence of institutions that may facilitate policy integration as a first step toward understanding the nexus among climate, energy, and water policies.

\section{The institutional challenge}

To manage climate change and to sustain water resources and ecosystems, institutional settings must promote integrated approaches to optimizing outcomes in different sectors, including for water, biodiversity, climate, and energy (Bates et al. 2008, MEA 2005a). In the United Nations Framework Convention on Climate Change (UNFCCC), the world's governments have committed to address climate change in an integrated and holistic manner (United Nations (UN) 1992b) to prevent dangerous climate change (Article 2 ) by implementing national programs for mitigation and adequate adaptation to climate change (Article 4.1(b)), and by taking climate change considerations into account, to the extent feasible, in their relevant social, economic, and environmental policies and actions (Article 4.1 (f)). In other international agreements, national governments have committed to achieve: wise use of all wetlands (including rivers and estuaries) (Ramsar Secretariat 2009); significant reductions in the rate of loss of biodiversity by 2010 (UN 1992a); and halving of poverty by 2015 , including through the expansion of water-dependent services (United Nations General Assembly (UNGA) 2000).

Solutions to environmental problems, such as climate change and water resource degradation, require long-term integration of economic, social, 
and environmental policies, and this poses challenges for governmental systems. This research considers the types of institutions that may promote effective integration of climate and water policies. Climate change policy is a subset of sustainable development or environmental policy and is similarly broad in geographic and sectoral scope (Dovers and Hezri 2010). Drawing on the debate on effective environmental policy integration, Ross and Dovers (2008) assessed Australian state and federal government institutions to identify administrative mechanisms. Four types of integrative institutions were identified, namely: constitutional mechanisms and legislation; horizontal and vertical coordinating mechanisms; lead agencies; and advisory, consultative, and review bodies. In this research, Ross and Dovers' (2008) framework is adapted and applied as an objective means of assessing and comparing investments by governments in integrated policy development, implementation, and adaptation. Focusing on national climate change institutions, this assessment identifies examples and lessons and then draws conclusions for more effective integration of climate change policies with sustainable water management and other objectives.

\section{METHODS}

The policy analysis undertaken in this research is focused on policy style and detail (Dovers 2005) and based on the adopted policies of the jurisdictions concerned. This initial assessment is an overview of institutional design and policies in isolation, described as "thin institutionalism," rather than also assessing the rules in use ("new" or "thick" intuitionalism) (Young 2002), which would be a logical next step to follow up the key findings from this research. Identifying trends, barriers, and better practices in actual policy settings is an essential first step in understanding government priorities and choices in managing this integration issue, which has only recently received attention in the context of climate change.

Integration among key components of energy, water, and climate policies has been assessed in a small number of jurisdictions, notably in Australia (Proust et al. 2007, Smart and Aspinall 2009, Newell et al. 2011), the United Kingdom (Reffold et al. 2008), and the United States (Inhaber 2004, Hightower and Pierce 2008, Stillwell et al. 2011). However, lack of a structured assessment of a broader sample of countries to identify trends and issues is a major gap addressed by this research. In order to balance the need for depth of research vs. breadth of geographic coverage, nine jurisdictions were selected for assessment to cover a range of geographic and economic settings. Case-study jurisdictions were chosen on the basis of the following criteria:

1. breadth, involving assessment across nine jurisdictions, rather than focusing on a few countries in depth, which would provide little scope for comparison;

2. a range of countries representing varying degrees of development, including least developed, countries with emerging economies, and developed nations;

3. jurisdictions where physical or economic water scarcity is a problem in at least a significant part of the nation (CAoWMiA 2007), which may be anticipated to drive integration of relevant policies;

4. the presence of relevant sectoral policies; and

5. sufficient and accessible material describing policy content.

Access to material was aided by the author's ongoing research in most of these jurisdictions with the environmental organization, WWF, which assisted in locating policy data, including through advice from local WWF staff (Pittock 2009b).

In addition to using research and data compiled from on-going WWF-funded research, the national climate change policies were located online from the governments concerned or from the UNFCCC's database, and those used are listed in Table 1. This research has also drawn on the relevant water and energy policies for these jurisdictions. These were mainly accessed in May and August 2009. The policies for the United Kingdom apply primarily to England and Wales. The data were checked with colleagues in these countries to ensure that an accurate overview of the key policies was assessed in this research. In a few instances, where countries have not formally adopted a policy or policies, statements by government officials, draft policies, or other government documents have been used, as indicated in Table 1. 
Table 1. Policy data sources by jurisdiction

\begin{tabular}{|c|c|c|c|c|c|}
\hline Jurisdiction & Climate & Energy & Water & Biodiversity & $\begin{array}{l}\text { National priorities / 5- } \\
\text { year plan }\end{array}$ \\
\hline Australia & $\begin{array}{l}\text { Carbon Pollution } \\
\text { Reduction Scheme Bill } \\
\text { 2009; National Climate } \\
\text { Change Adaptation } \\
\text { Framework } 2007\end{array}$ & $\begin{array}{l}\text { Renewable Energy } \\
\text { Demonstration Program 2009; } \\
\text { Global Carbon Capture and } \\
\text { Storage Institute 2009; Low } \\
\text { Emissions Technology } \\
\text { Demonstration Fund 2006 }\end{array}$ & $\begin{array}{l}\text { National } \\
\text { Water } \\
\text { Initiative 2004, } \\
\text { Water Act } \\
2008\end{array}$ & $\begin{array}{l}\text { 1996 National } \\
\text { Strategy }\end{array}$ & $\begin{array}{l}\text { No formal statement, } \\
\text { climate and water were } \\
\text { key issues in } 2007 \\
\text { election }\end{array}$ \\
\hline $\begin{array}{l}\text { European } \\
\text { Union }\end{array}$ & $\begin{array}{l}\text { White Paper, Adapting to } \\
\text { climate change, towards an } \\
\text { European framework for } \\
\text { action } 2009\end{array}$ & $\begin{array}{l}\text { Framework for the promotion } \\
\text { of energy from renewable } \\
\text { sources 2009; Emission } \\
\text { Trading System 2009; } \\
\text { standards for fuels and biofuels } \\
2009 ; \text { regulatory framework for } \\
\text { carbon capture and storage } \\
2009\end{array}$ & $\begin{array}{l}\text { Water } \\
\text { Framework } \\
\text { Directive } 2001\end{array}$ & $\begin{array}{l}\text { Biodiversity } \\
\text { action plans } 2001\end{array}$ & $\begin{array}{l}\text { 2005-2009 EU strategic } \\
\text { directives }\end{array}$ \\
\hline $\begin{array}{l}\text { England } \\
\text { and Wales }\end{array}$ & $\begin{array}{l}\text { The Climate Change Act } \\
\text { 2008; Adapting to Climate } \\
\text { Change Programme } 2008\end{array}$ & $\begin{array}{l}\text { Meeting the Energy Challenge: } \\
\text { a White Paper on Energy May } \\
\text { 2007; Energy Act } 2008\end{array}$ & $\begin{array}{l}\text { Water } \\
\text { Resources } \\
\text { Strategy for } \\
\text { England \& } \\
\text { Wales 2009 }\end{array}$ & $\begin{array}{l}\text { Conserving } \\
\text { biodiversity-the } \\
\text { UK approach } \\
2007\end{array}$ & $\begin{array}{l}\text { No national priority } \\
\text { statement or long-term } \\
\text { plan was found }\end{array}$ \\
\hline Brazil & $\begin{array}{l}\text { Executive Summary } \\
\text { National plan on Climate } \\
\text { Change, } 2008\end{array}$ & $\begin{array}{l}\text { National Energy Plan 2005- } \\
2030,2006 \text { hydroelectricity } \\
\text { plan }\end{array}$ & $\begin{array}{l}\text { National } \\
\text { Water Act } \\
1997 \text { and plan }\end{array}$ & $\begin{array}{l}\text { National } \\
\text { Biodiversity } \\
\text { Policy } 2002\end{array}$ & $\begin{array}{l}\text { Yes, but no integration } \\
\text { was apparent }\end{array}$ \\
\hline China & $\begin{array}{l}\text { China's National Climate } \\
\text { Change Program }\end{array}$ & Water law 2002 & $\begin{array}{l}\text { By sub-sector } \\
\text {-renewable } \\
\text { energy } 2007\end{array}$ & $\begin{array}{l}\text { National } \\
\text { Biodiversity } \\
\text { Strategy or } \\
\text { Action Plan, } \\
1994 \text { Action Plan }\end{array}$ & $\begin{array}{l}\text { Yes, } 11^{\text {th }} 5 \text {-year plan, } \\
\text { integration was apparent }\end{array}$ \\
\hline India & $\begin{array}{l}\text { National Action Plan on } \\
\text { Climate Change } 2008\end{array}$ & Energy Policy 2007 & $\begin{array}{l}\text { National } \\
\text { Water Policy } \\
2002\end{array}$ & $\begin{array}{l}2006 \\
\text { Environmental } \\
\text { Policy }\end{array}$ & $\begin{array}{l}\text { Yes, but no integration } \\
\text { was apparent }\end{array}$ \\
\hline Mexico & $\begin{array}{l}\text { National Strategy on } \\
\text { Climate Change } 2007, \\
\text { Executive Summary. } \\
\text { Special Program on } \\
\text { Climate Change } 2009\end{array}$ & $\begin{array}{l}\text { National Energy Program } \\
\text { 2007-2012 }\end{array}$ & $\begin{array}{l}\text { National } \\
\text { Water Plan } \\
\text { 2007-2012 }\end{array}$ & $\begin{array}{l}2000 \text { National } \\
\text { Biodiversity } \\
\text { Strategy or } \\
\text { Action Plan }\end{array}$ & $\begin{array}{l}\text { Yes, 5-year National } \\
\text { Development Plan } \\
\text { incorporates mitigation } \\
\text { measures }\end{array}$ \\
\hline $\begin{array}{l}\text { South } \\
\text { Africa }\end{array}$ & $\begin{array}{l}\text { South Africa Initial } \\
\text { Communication Under the } \\
\text { United Nations Framework } \\
\text { on Climate Change 2000; } \\
\text { Ministerial media release } \\
\text { and presentation, } 28 \text { July } \\
2008\end{array}$ & Integrated Energy Plan 2003 & $\begin{array}{l}\text { Water Act } \\
1998\end{array}$ & Final draft 2005 & $\begin{array}{l}\text { Not listed as key issues } \\
\text { on www.gov.za } \\
\text { in March } 2009\end{array}$ \\
\hline Tanzania & $\begin{array}{l}\text { United Republic of } \\
\text { Tanzania National } \\
\text { Adaptation Program of } \\
\text { Action } 2007\end{array}$ & $\mathrm{n} / \mathrm{a}$ & $\begin{array}{l}\text { 1991 Water } \\
\text { Policy }\end{array}$ & $\begin{array}{l}1997 \\
\text { Environment } \\
\text { Policy }\end{array}$ & $\begin{array}{l}\text { Not listed as key issues } \\
\text { on www.tanzania.gov.tz } \\
\text { in May } 2009\end{array}$ \\
\hline
\end{tabular}


The research has three components. Firstly, the water use implications in government climate policy priorities for greenhouse gas mitigation measures were assessed. Secondly, the water-related aspects of climate adaptation policy were examined. Finally, the institutional mechanisms for integrating climate policy with other sectors were reviewed. The methodologies applied are as follows.

\section{Climate policy and water-related greenhouse gas mitigation measures}

The extent to which climate mitigation policies consider water resources implications was assessed by noting the priority afforded to energy and carbon sequestration technologies with large water footprints (Inhaber 2004, Gerbens-Leenes et al. 2008), or alternatively, where better water management can contribute to carbon mitigation. Although not regarded as a technology with a large water footprint, nuclear power was included due to the high risk that these plants will need to be shut down in periods of water scarcity or in heat waves, such as that experienced in France in 2003, or operate and compromise freshwater ecosystems (Hightower and Pierce 2008). Scoring was undertaken on a three-point scale:

- $\mathrm{T}$ (green) = technology favored with quantitative targets for deployment;

- $\mathrm{Y}($ yellow $)=$ prioritized but without a quantum for implementation, or the technology is actively encouraged via a general emission trading scheme; and

- $\quad \mathrm{N}($ green $)=$ technology is not specifically cited.

Measures foreshadowed for research, such as carbon capture and storage in China, were not included, nor were emissions trading schemes cited without a commitment to implementation, as in Mexico. Although many policies include generic commitments to such measures as energy efficiency, they were only scored positively if a water-related technology was cited, such as greater efficiency in water supply systems. "Water focus" is a qualitative judgment by the author on the importance of the water-related technologies as a portion of the measures proposed in the national mitigation policy on a three-point scale of low, medium, or high.

\section{Climate adaptation policy and water-related measures}

The extent to which national policies on climate change adaptation incorporated water resources was assessed based on the relevant climate change, water, or other appropriate policies and laws. Scoring was undertaken on a three-point scale:

- $\mathrm{Y}($ green $)=$ yes, the measure is favored (or T $=$ target set);

- In part (yellow $)=$ partial application of the measure;

- $\quad \mathrm{N}($ red $)=$ no, the measure is not specifically cited.

Generic policies for more research and capacity building, other than monitoring, modeling, and early warning, were not identified separately but are common to almost all of these adaptation strategies. Other categories describe the types of water-related adaptation interventions commonly prioritized in national climate adaptation and water policies.

\section{Climate policy: institutional settings for integration}

Drawing on Ross and Dovers' (2008) framework, the institutional settings in each jurisdiction for integrating climate change policies within government, and across different levels of government and sectors, as well as for identifying and avoiding perverse outcomes, were assessed on a three-point scale:

- $\quad \mathrm{Y}($ green $)=$ established institution;

- In part (yellow) $=$ a measure that partially fulfills this function is in place;

- $\quad \mathrm{N}($ red $)=$ no institution is in place.

Three constitutional mechanisms and legislation were assessed, namely:

1. legislation that codifies measures to respond to climate change;

2. integrated climate policy that combines measures for both climate mitigation and adaptation; and 
3. iterative processes that ensure that climate response measures are periodically reviewed and updated to incorporate new knowledge.

Two main coordinating mechanisms were considered. Firstly, the quality of intragovernmental institutions that bring together different sectoral agencies of government to develop whole-of-government climate policies was assessed. Ideally, this horizontal integration mechanism is in addition to regular institutions, such as cabinet meetings, so as to provide specific expertise and resources to manage climate change. Secondly, inter-governmental institutions were examined, which bring together national (or EU), provincial (or EU Member States), and local levels of government to progress climate policies. Ideally, this vertical integration mechanism is in addition to regular institutions, such as heads of government or parliamentary (e.g., senate) processes, so as to provide specific expertise and resources to manage climate change. The designation of lead agencies was considered, namely government institutions with the capacity to coordinate, integrate, influence, and enhance climate policy implementation across government, which usually report to either the first minister (Prime Minister or President). Ideally, they should have the capacity to influence all government portfolios and be captured by none.

Three types of advisory, consultative, and review bodies were also assessed. Firstly, multistakeholder institutions were examined, that bring together civil society and business representatives from different sectors to inform government climate policy development and promote implementation. Secondly, the presence of an independent government body that provides "objective" and public reports to parliament or senior government leaders on environmental problems and solutions was assessed, such as a commissioner for the environment or sustainable development commission. Finally, provision for periodic and public state-ofthe-environment reports to parliament and/or senior government leaders on environmental problems and solutions was considered.

\section{RESULTS}

The water-related aspects of the national climate change mitigation and adaptation policies were assessed and tabulated. Table 2 shows the extent to which national climate mitigation policies have implications for water resources.

Table 3 depicts the extent to which national policies on climate change adaptation incorporate water resources based on the relevant climate change, water, or other appropriate policies and laws.

Table 4 shows the institutional settings in each jurisdiction for integrating climate change policies within governments, across different levels of government and sectors, as well as for identifying and avoiding perverse outcomes.

\section{DISCUSSION OF NATIONAL POLICIES- DEVELOPED NATIONS}

\section{Australia}

Australia's national climate policies amount to an ad hoc collection of discrete and conflicting measures, which also do not consider conflicts in sustaining water resources and ecosystems. These measures have focused on the reduction of carbon emissions (Government of Australia 2008), including through subsidies for biofuel production and the promotion of carbon capture and storage, although there has been no consideration of their water use impacts. An independent government adviser has also promoted retrofitting existing hydropower dams as pumped storage operations to store excess energy from new wind farms (Garnaut 2008). A proposed Carbon Farming Initiative could see carbon credits funding carbon sequestration through afforestation without apparent consideration of resulting reductions of runoff (Department of Climate Change and Energy Efficiency (DCCEE) 2010). The government's on-again, off-again attempts to set a price on carbon (Government of Australia 2008) may exacerbate these conflicts with water resources if implemented poorly. Australian energy, water, and climate policies are beset with conflicting subsidies and incentives, including: mandatory renewable energy targets, subsidies for biofuel production and carbon capture and storage, and a diesel fuel rebate the favors the fossil fuels sector. This lack of integrated action contrasts with more sophisticated work in water-sector institutions, including the National Water Initiative (Commonwealth of Australia et al. 2004) and the Agreement on Murray Darling Basin Reform (Commonwealth of 
Table 2. Climate policy and water-related greenhouse gas mitigation measures

\begin{tabular}{|c|c|c|c|c|c|c|c|c|c|c|}
\hline \multirow[b]{2}{*}{ Jurisdiction } & \multirow[b]{2}{*}{$\begin{array}{l}\text { Water } \\
\text { focus }\end{array}$} & \multicolumn{4}{|c|}{ Energy generation } & \multicolumn{3}{|c|}{ Carbon sequestration } & \multicolumn{2}{|c|}{$\begin{array}{l}\text { Other mitigation and } \\
\text { water }\end{array}$} \\
\hline & & Biomass & $\begin{array}{c}\text { New } \\
\text { hydropower }\end{array}$ & $\begin{array}{c}\text { Pumped } \\
\text { storage } \\
\text { hydropower }\end{array}$ & Nuclear & $\begin{array}{l}\text { Carbon } \\
\text { capture } \\
\text { and } \\
\text { storage }\end{array}$ & $\begin{array}{l}\text { Forestry } \\
\text { expansion }\end{array}$ & $\begin{array}{l}\text { Wetlands } \\
\text { conservation }\end{array}$ & $\begin{array}{l}\text { Energy } \\
\text { efficiency } \\
\text { in water }\end{array}$ & $\begin{array}{l}\text { Energy } \\
\text { from } \\
\text { sewage }\end{array}$ \\
\hline Australia & Low & $\mathrm{Y}$ & $\mathrm{N}$ & $\mathrm{N}$ & $\mathrm{N}$ & $\mathrm{Y}$ & $\mathrm{Y}$ & $\mathrm{N}$ & $\mathrm{N}$ & $\mathrm{N}$ \\
\hline $\begin{array}{c}\text { European } \\
\text { Union }\end{array}$ & Medium & $\mathrm{T}$ & $\mathrm{Y}$ & $\mathrm{Y}$ & $\mathrm{Y}$ & $\mathrm{Y}$ & $\mathrm{N}$ & $\mathrm{N}$ & $\mathrm{N}$ & $\mathrm{N}$ \\
\hline $\begin{array}{l}\text { England } \\
\text { and Wales }\end{array}$ & Low & $\mathrm{Y}$ & $\mathrm{N}$ & $\mathrm{N}$ & $\mathrm{T}$ & $\mathrm{T}$ & $\mathrm{N}$ & $\mathrm{N}$ & $\mathrm{Y}$ & $\mathrm{N}$ \\
\hline Brazil & High & $\mathrm{Y}$ & $\mathrm{T}$ & $\mathrm{N}$ & $\mathrm{Y}$ & $\mathrm{N}$ & $\mathrm{Y}$ & $\mathrm{N}$ & $\mathrm{N}$ & $\mathrm{N}$ \\
\hline China & High & $\mathrm{T}$ & $\mathrm{T}$ & $\mathrm{N}$ & $\mathrm{T}$ & $\mathrm{N}$ & $\mathrm{T}$ & $\mathrm{Y}$ & $\mathrm{N}$ & $\mathrm{T}$ \\
\hline India & High & $\mathrm{T}$ & $\mathrm{T}$ & $\mathrm{T}$ & $\mathrm{T}$ & $\mathrm{N}$ & $\mathrm{T}$ & $\mathrm{N}$ & $\mathrm{Y}$ & $\mathrm{Y}$ \\
\hline Mexico & Low & $\mathrm{T}$ & $\mathrm{T}$ & $\mathrm{N}$ & $\mathrm{N}$ & $\mathrm{N}$ & $\mathrm{T}$ & $\mathrm{N}$ & $\mathrm{N}$ & $\mathrm{N}$ \\
\hline $\begin{array}{l}\text { South } \\
\text { Africa }\end{array}$ & Low & $\mathrm{N}$ & $\mathrm{Y}$ & $\mathrm{N}$ & $\mathrm{T}$ & $\mathrm{Y}$ & $\mathrm{Y}$ & $\mathrm{N}$ & $\mathrm{Y}$ & $\mathrm{N}$ \\
\hline Tanzania & Medium & $\mathrm{Y}$ & $\mathrm{Y}$ & $\mathrm{N}$ & $\mathrm{N}$ & $\mathrm{N}$ & $\mathrm{Y}$ & $\mathrm{N}$ & $\mathrm{N}$ & $\mathrm{N}$ \\
\hline
\end{tabular}

Australia et al. 2008) that are incorporating much more practical, target-driven measures to adapt to climate change.

Despite the lack of a coherent national climate change policy, the then newly elected Australian government created an independent Department of Climate Change in 2008, with a cabinet minister reporting directly to the Prime Minister. There is also a sub-committee of cabinet. Although leadership at the highest political level is likely to enhance Australia's climate change responses, measures may also be needed to ensure that other government agencies adequately collaborate with the new department and implement climate change mitigation and adaptation measures. Australia appears to lack the most common integrative institutions at the national scale.

\section{European Union}

The EU is an example of a jurisdiction that has strong sectoral policies that are poorly integrated, as illustrated by a climate change mitigation policy that did not initially and still does not effectively manage the perverse impacts on freshwater resources and ecosystems. The EU's Energy and Climate Change Policy 2007 known as 20:20 by 2020 (20\% less emissions and $20 \%$ more renewable energy by 2020) is implemented in part through an emissions trading scheme (European Commission 2008). Notably, the policy substantially conflates climate change and energy initiatives. The adoption of a target for $10 \%$ of all transport fuels to come from biofuels by 2020 sparked a backlash based on concerns of potential impacts on people, habitats, and water, and resulted in the adoption of minimum standards for biofuels sold in the UK. A similar debate over the standards applying to Clean Development Mechanism hydropower Certified 
Table 3. Climate adaptation policy and water related measures

\begin{tabular}{|c|c|c|c|c|c|c|c|c|c|c|c|}
\hline \multirow{2}{*}{ Jurisdiction } & \multirow{2}{*}{$\begin{array}{l}\text { Water } \\
\text { focus }\end{array}$} & \multirow{2}{*}{$\begin{array}{l}\text { Hydro- } \\
\text { climatic } \\
\text { monitoring, } \\
\text { modeling } \\
\text { and early } \\
\text { warning }\end{array}$} & \multicolumn{5}{|c|}{ Supply side } & \multicolumn{4}{|c|}{ Efficiency and environmental restoration } \\
\hline & & & $\begin{array}{l}\text { More } \\
\text { surface } \\
\text { storage }\end{array}$ & $\begin{array}{l}\text { Interbasin } \\
\text { transfers }\end{array}$ & $\begin{array}{l}\text { Groundwater } \\
\text { management }\end{array}$ & $\begin{array}{l}\text { Rainwater } \\
\text { harvesting }\end{array}$ & Desalination & $\begin{array}{l}\text { Greater } \\
\text { efficiency }\end{array}$ & $\begin{array}{l}\text { Re- } \\
\text { allocation }\end{array}$ & $\begin{array}{l}\text { Restoration } \\
\text { of water } \\
\text { sources / } \\
\text { catchments }\end{array}$ & $\begin{array}{l}\text { Restoration } \\
\text { of } \\
\text { floodplains }\end{array}$ \\
\hline Australia & Low & $\mathrm{T}$ & $\mathrm{N}$ & $\mathrm{T}$ & $\mathrm{T}$ & $\mathrm{N}$ & $\mathrm{T}$ & $\mathrm{T}$ & $\mathrm{T}$ & $\mathrm{N}$ & $\mathrm{N}$ \\
\hline $\begin{array}{l}\text { European } \\
\text { Union }\end{array}$ & High & $\begin{array}{l}\text { In part - } \\
\text { vulnerability } \\
\text { focus }\end{array}$ & $\mathrm{N}$ & $\mathrm{N}$ & $\mathrm{Y}$ & $\mathrm{N}$ & $\mathrm{N}$ & $\mathrm{Y}$ & $\mathrm{N}$ & $\mathrm{Y}$ & $\begin{array}{l}\text { In part - } \\
\text { inferred }\end{array}$ \\
\hline $\begin{array}{l}\text { England } \\
\text { and Wales }\end{array}$ & $\begin{array}{l}\text { Medi- } \\
\text { um }\end{array}$ & $\mathrm{Y}$ & $\mathrm{Y}$ & $\mathrm{Y}$ & $\mathrm{Y}$ & $\mathrm{Y}$ & $\mathrm{Y}$ & $\mathrm{Y}$ & $\mathrm{Y}$ & Y & Y \\
\hline Brazil & Low & $\mathrm{Y}$ & $\mathrm{N}$ & $\mathrm{Y}$ & $\mathrm{N}$ & In part & $\mathrm{N}$ & $\mathrm{N}$ & $\mathrm{N}$ & $\mathrm{N}$ & $\mathrm{N}$ \\
\hline China & High & $\mathrm{Y}$ & $\mathrm{Y}$ & $\mathrm{T}$ & $\mathrm{Y}$ & $\mathrm{Y}$ & $\mathrm{Y}$ & Y & $\mathrm{Y}$ & $\mathrm{Y}$ & $\mathrm{Y}$ \\
\hline India & High & $\mathrm{Y}$ & $\mathrm{Y}$ & Y & $\mathrm{Y}$ & $\mathrm{Y}$ & $\mathrm{Y}$ & $\mathrm{T}$ & $\mathrm{N}$ & Y & $\mathrm{N}$ \\
\hline Mexico & $\begin{array}{l}\text { Medi- } \\
\text { um }\end{array}$ & $\mathrm{Y}$ & $\mathrm{N}$ & $\mathrm{N}$ & $\mathrm{Y}$ & $\mathrm{N}$ & $\mathrm{N}$ & $\mathrm{N}$ & $\mathrm{N}$ & $\mathrm{Y}$ & $\mathrm{N}$ \\
\hline $\begin{array}{l}\text { South } \\
\text { Africa }\end{array}$ & Low & $\mathrm{Y}$ & $\mathrm{Y}$ & Y & $\mathrm{N}$ & $\mathrm{Y}$ & $\mathrm{N}$ & $\mathrm{Y}$ & $\mathrm{Y}$ & $\begin{array}{l}\text { In part - } \\
\text { inferred }\end{array}$ & $\mathrm{N}$ \\
\hline Tanzania & High & $\mathrm{Y}$ & $\mathrm{Y}$ & $\mathrm{Y}$ & $\mathrm{Y}$ & $\mathrm{Y}$ & $\mathrm{Y}$ & $\mathrm{Y}$ & $\mathrm{N}$ & $\mathrm{Y}$ & $\mathrm{N}$ \\
\hline
\end{tabular}

Emission Reduction certificates purchased into the European emission trading scheme has exposed the need for more robust certification procedures (Pittock 2010a). New water-related developments within the EU are regulated by their rigorous Water Framework Directive (European Commission 2001) that requires "good" ecological status to be achieved for all EU waters by 2015. The Directive gives priority to implementation of environmental flows, and approvals for new water infrastructure are likely to be limited. The EU's adaptation policy (European Commission 2007, van Nood 2008) proposes to focus on three main responses: enhancing human capacities; green infrastructureworking with nature to reduce impacts, such as by restoring floodplains; and gray infrastructureclimate proofing existing and future infrastructure. It is notable that the adaptation policy is lagging behind the mitigation measures: a comprehensive policy is not proposed until 2013.

A key feature of the EU institutional framework is that these directives can be enforced through thirdparty complaints and by the European Commission and European Court of Justice, resulting in very large fines for non-compliant member states. Perhaps because of the multitude of mainstream integrative mechanisms, sometimes described as the "open method of policy coordination" and "networked governance" (Hodson and Maher 2001, Laffan 2001, Schout and Jordan 2005) (albeit often criticized for inadequate environmental policy integration), the EU appears to lack many common integrative climate change policy institutions. 
Table 4. Climate policy institutional settings Note: $\mathrm{CC}=$ climate change.

\begin{tabular}{|c|c|c|c|c|c|c|c|c|c|}
\hline Jurisdiction & Legislation & $\begin{array}{l}\text { Integrated } \\
\text { climate } \\
\text { policy } \\
\text { (mitigation } \\
\text { and } \\
\text { adaptation) }\end{array}$ & Iterative policy & $\begin{array}{l}\text { Intra- } \\
\text { governmental } \\
\text { institution } / \mathrm{s}\end{array}$ & $\begin{array}{l}\text { Inter- } \\
\text { governmental } \\
\text { institution } / \mathrm{s}\end{array}$ & $\begin{array}{l}\text { Central policy } \\
\text { unit }\end{array}$ & $\begin{array}{l}\text { Multi- } \\
\text { stakeholder } \\
\text { institution/s }\end{array}$ & $\begin{array}{l}\text { Commissioner } \\
\text { for the } \\
\text { environment }\end{array}$ & $\begin{array}{l}\text { State-of-the- } \\
\text { environment } \\
\text { reporting }\end{array}$ \\
\hline Australia & $\begin{array}{l}\text { In part - } \\
\text { ETS law } \\
\text { tabled }\end{array}$ & $\mathrm{N}$ & $\mathrm{N}$ & $\begin{array}{l}\text { In part - Sub- } \\
\text { Committee of } \\
\text { Cabinet }\end{array}$ & $\mathrm{N}$ & $\begin{array}{l}\text { In part - Dept } \\
\text { of CC }\end{array}$ & $\mathrm{N}$ & $\mathrm{N}$ & $\mathrm{Y}$ \\
\hline $\begin{array}{l}\text { European } \\
\text { Union }\end{array}$ & $\begin{array}{l}\text { Y - 2009 } \\
\text { legislative } \\
\text { package }\end{array}$ & $\begin{array}{l}\mathrm{N} \text {-policies } \\
\text { separate }\end{array}$ & $\begin{array}{l}\mathrm{Y}-\text { cyclical } \\
\text { policy review }\end{array}$ & $\mathrm{N}$ & $\begin{array}{l}\text { In part - } \\
\text { proposed } \\
\text { Impact and } \\
\text { Adaptation } \\
\text { Steering } \\
\text { Group }\end{array}$ & $\begin{array}{l}\mathrm{N}-\mathrm{DG} \\
\text { Environment }\end{array}$ & $\mathrm{N}$ & $\begin{array}{l}\text { In part }-\mathrm{EC} \\
\text { plays this role }\end{array}$ & $\mathrm{Y}$ \\
\hline $\begin{array}{l}\text { United } \\
\text { Kingdom }\end{array}$ & $\begin{array}{l}\text { Y - The } \\
\text { CC Act } \\
2008\end{array}$ & $\begin{array}{l}\text { Y - The CC } \\
\text { Act } 2008\end{array}$ & $\begin{array}{l}\mathrm{Y}-5 \text { yearly } \\
\text { program cycle }\end{array}$ & $\mathrm{N}$ & $\begin{array}{l}\text { In part - } \\
\text { Adapting to } \\
\text { CC UK group }\end{array}$ & $\begin{array}{l}\text { In part - Dept } \\
\text { of Energy and } \\
\text { CC }\end{array}$ & $\mathrm{N}$ & $\begin{array}{l}\text { Y - } \\
\text { Sustainable } \\
\text { Development } \\
\text { Commission } \\
\text { In part - } \\
\text { Committee on } \\
\text { CC }\end{array}$ & $\begin{array}{l}\text { In part - } \\
\text { Sustainable } \\
\text { Development } \\
\text { Commission, } \\
\text { focused on } \\
\text { government }\end{array}$ \\
\hline Brazil & $\mathrm{N}$ & $\begin{array}{l}\text { In part - } \\
2008 . \\
\text { Adaptation } \\
\text { is weak }\end{array}$ & $\begin{array}{l}\text { Y- } \\
\text { implementation } \\
\text { through 5-year } \\
\text { plans }\end{array}$ & $\begin{array}{l}\text { Y - Inter- } \\
\text { Ministerial } \\
\text { Committee on } \\
\text { CC }\end{array}$ & $\begin{array}{l}\text { Y - Brazilian } \\
\text { Forum on CC }\end{array}$ & $\begin{array}{l}\text { Y - Office of } \\
\text { the President }\end{array}$ & $\begin{array}{l}\text { Y - } \\
\text { Brazilian } \\
\text { Forum on } \\
\text { CC }\end{array}$ & $\begin{array}{l}\text { Y - Secretaria } \\
\text { de Assuntos } \\
\text { Estratégicos }\end{array}$ & $\mathrm{N}$ \\
\hline China & $\mathrm{N}$ & Y - 2007 & $\begin{array}{l}\text { Y - } \\
\text { implementation } \\
\text { through 5-year } \\
\text { plans }\end{array}$ & $\begin{array}{l}\text { Y - National } \\
\text { Coordination } \\
\text { Committee on } \\
\text { CC }\end{array}$ & $\begin{array}{l}\text { Y - system for } \\
\text { coordinating } \\
\text { work, } \\
\text { including } \\
\text { between } \\
\text { national \& } \\
\text { local } \\
\text { governments }\end{array}$ & $\begin{array}{l}\text { Y - National } \\
\text { Leading Group } \\
\text { to Address } \\
\text { CC, National } \\
\text { Development } \\
\text { \& Reform } \\
\text { Comm. }\end{array}$ & $\mathrm{N}$ & $\mathrm{N}$ & $\mathrm{N}$ \\
\hline India & $\mathrm{N}$ & Y - 2008 & $\begin{array}{l}\mathrm{Y}- \\
\text { implementation } \\
\text { through 5-year } \\
\text { plans }\end{array}$ & $\begin{array}{l}\text { Y - } \\
\text { Coordination } \\
\text { Unit for } \\
\text { Implementation } \\
\text { of nat. plan }\end{array}$ & $\mathrm{N}$ & $\begin{array}{l}\mathrm{N}-\text { Ministry } \\
\text { for } \\
\text { Environment } \\
\text { and Forests }\end{array}$ & $\begin{array}{l}\text { Y- } \\
\text { Advisory } \\
\text { Council on } \\
\text { Climate } \\
\text { Change }\end{array}$ & $\mathrm{N}$ & $\mathrm{N}$ \\
\hline Mexico & $\mathrm{N}$ & $\begin{array}{l}\text { Y - Special } \\
\text { program on } \\
\text { CC } 2009\end{array}$ & $\mathrm{~N}$ & $\begin{array}{l}\text { Y - } \\
\text { Intersecretarial } \\
\text { Commission } \\
\text { on CC }\end{array}$ & $\mathrm{N}$ & $\begin{array}{l}\mathrm{N}- \\
\text { SEMARNAT }\end{array}$ & $\begin{array}{l}\text { Y - } \\
\text { Consultative } \\
\text { Council on } \\
\text { CC }\end{array}$ & $\mathrm{N}$ & $\mathrm{N}$ \\
\hline $\begin{array}{l}\text { South } \\
\text { Africa }\end{array}$ & $\mathrm{N}$ & $\mathrm{N}$ & $\mathrm{N}$ & $\begin{array}{l}\text { Y - Inter- } \\
\text { departmental } \\
\text { Committee } \\
\text { advises } \\
\text { Minister for } \\
\text { DEAT }\end{array}$ & $\mathrm{N}$ & $\begin{array}{l}\mathrm{N} \text { - Dept } \\
\text { Environmental } \\
\text { Affairs and } \\
\text { Tourism }\end{array}$ & $\begin{array}{l}\text { Y - } \\
\text { Advisory } \\
\text { Committee } \\
\text { to DEAT }\end{array}$ & $\mathrm{N}$ & $\mathrm{N}$ \\
\hline Tanzania & $\mathrm{N}$ & Y - 1997 & $\mathrm{~N}$ & $\begin{array}{l}\text { Y - The } \\
\text { National CC } \\
\text { Committee }\end{array}$ & $\begin{array}{l}\text { Y - The } \\
\text { National CC } \\
\text { Committee }\end{array}$ & $\begin{array}{l}\text { In part - Vice- } \\
\text { President's } \\
\text { Office, } \\
\text { Division of } \\
\text { Environment }\end{array}$ & $\begin{array}{l}\text { In part - } \\
\text { one non- } \\
\text { gov. } \\
\text { member on } \\
\text { NCCC }\end{array}$ & $\mathrm{N}$ & $\mathrm{N}$ \\
\hline
\end{tabular}




\section{England and Wales}

The United Kingdom's government, in its policies that apply to England and Wales, has legislated for substantial reductions in greenhouse gas emissions in its Climate Change Act (HM Government 2008b), including in the water sector. However, linked energy policy measures would appear to favor, among other policies, greater application of biofuels, carbon capture and storage, and nuclear power that would consume more water. The government has formed a new Department of Energy and Climate Change to lead these initiatives. The Adapting to Climate Change Programme for England (HM Government 2008a) appears vague and research oriented, with few specific measures or targets. This contrasts markedly with the Environment Agency's Water Resources Strategy for England and Wales (EA 2009), which proposes a sophisticated range of specific climate adaptation measures, even if they lack targets. The UK contrasts with other jurisdictions in having an independent and expert-based Committee on Climate Change, but in other respects apparently lacks integrative mechanisms.

\section{Commonalities among developed jurisdictions}

The three developed jurisdictions discussed here have a number of common elements in their approaches to climate change and water: in particular, they substantially conflate climate and energy policies, as reflected in legislation and the structures of government. Despite having regions with major water scarcity problems, these countries have each adopted climate mitigation measures that may substantially impact on water resources without recognizing and managing the conflict. Their adaptation plans lag behind climate mitigation policies and tend to consist of vague measures and proposals for more research. In Australia and the $\mathrm{UK}$, in parallel policy initiatives, it is government water agencies that appear to have developed more specific and practical climate adaptation measures. Despite urging developed countries to enhance their governance, these measures are often lacking in these developed jurisdictions, for instance, none have multi-stakeholder advisory institutions on climate change.

\section{DISCUSSION OF NATIONAL POLICIES- DEVELOPING NATIONS}

\section{Brazil}

Brazil's National Plan on Climate Change (Government of Brazil 2008), despite its claims to integration, focuses largely on energy mitigation measures and fails to consider interaction with water resources and ecosystems. Major adaptation challenges are omitted, such as increasing water scarcity in northeast Brazil. The plan proposes boosting biofuel production from sugar cane (including increasing domestic ethanol use by $11 \%$ per year), and expanding hydroelectric generation by $34,460 \mathrm{GW}$ by 2016 , which could impact on freshwater ecosystem services. The considerable potential to increase hydropower production by upgrading existing dams is not explicitly recognized (World Wildlife Fund (WWF) 2004). Extensive afforestation is also proposed. Biofuels, hydropower, and afforestation have the potential to increase water consumption significantly.

However, the climate change policy processes have the potential to better integrate policy. The processes are underpinned by a number of presidential decrees, establishing influential institutions: a multi-stakeholder Brazilian Forum on Climate Change and an Inter-Ministerial Committee on Climate Change coordinated by the Office of the President. Day-to-day implementation of the national plan is delegated to an interdepartmental Executive Group on Climate Change coordinated by the Ministry of the Environment.

\section{China}

China's National Climate Change Program (Government of China 2007:25-50) includes a commitment to "integrate climate change policy with other interrelated policies," and there are substantial attempts to do this. This is reflected in the appointment of the powerful National Reform and Development Commission to lead the program, reporting to the State Council, and overseeing implementation by key agencies. This top-level leadership may need to be supported by further measures to promote collaboration among government agencies, accountability, and enforcement for effective implementation. 
A key water-related commitment is to reduce the vulnerability of water resources by 2010 with measures for: "rational exploitation" and allocation of water, building new infrastructure, and anti-flood engineering. The program also promises to "speed up building of the Project of South-to-North Water Diversion," the major interbasin transfer project to take water from the Yangtze River basin over a thousand kilometers to northern China. In terms of energy, China plans to promote the development of bioenergy and raise the proportion of renewable energy (including large-scale hydropower) to $10 \%$ by 2010 . The expansion of hydropower is qualified with the "precondition of protecting the ecosystem." The challenge of harmonizing hydropower development with nature is illustrated in the upper Yangtze River basin, where many proposed dams coincide with river reaches and sub-catchments identified as having high biodiversity conservation values. Hence, water resources and ecosystems are explicitly considered in Chinese climate change policies, but there are tensions between energy generation and water supply, and between "soft" and "hard" approaches to water management.

\section{India}

India has proposed a disparate range of climate change response measures that do consider water, but the implications for greater water consumption and other impacts on freshwater ecosystem services from the hydropower and biofuel targets would be negative and integration mechanisms are not proposed. The Indian National Action Plan on Climate Change (Government of India 2008) defines eight priority "missions." The political impetus behind the plan is questionable, with an advisory committee reporting to the Prime Minister and the Ministry of Environment and Forests delegated to coordinate implementation across Union Government agencies. Water is one of eight "national missions," and includes a target of increasing water use efficiency by $20 \%$. There are many "no and low regrets" freshwater adaptation measures proposed, such as: conjunctive management of groundwater, rainwater harvesting, tank restoration, wastewater reuse, and (reactive) wetlands conservation (Ministry of Water Resources (MWR) 2009), consistent with academic assessments of water management priorities (Gupta and Deshpande 2004, Amarasinghe et al. 2008). However, the climate policy reiterates support for the National Water Policy (MWR 2002), which has a greater emphasis on centralized water infrastructure, such as the proposed interlinking of rivers scheme (MWR 2009). On the ground, initiatives for soft-path measures, like rainwater harvesting and tank restoration are driven by nongovernment actors, whereas government support is often ineffective or favors major infrastructure schemes, such as the proposed Polavaram Dam (Gujja et al. 2006, 2009, Pittock 2009b). The focus on the Himalayas and forests is not explained given that other biomes and regions are likely to be significantly impacted. Extensive afforestation is proposed.

A massive expansion of hydropower generation is proposed from 30-35,000 MW to $133,700 \mathrm{MW}$. Uniquely among the national plans assessed, a target is set to install pumped storage schemes at 56 sites with 94,000 MW capacity. The policy on hydropower development (Government of India 1998) is for "Optimal harnessing of hydro potential in each river basin." Furthermore, targets are set for increased energy production from biofuels. The plan supports the 2002 national water policy for greater storage development, "interlinking" 37 rivers around the country (National Water Development Agency (NWDA) 2008), and desalination. These measures would have significant, perverse impacts on freshwater ecosystem services.

\section{Mexico}

Mexico has substantial climate change policies, but the implications for water resources and ecosystems are mixed and mechanisms for sub-national implementation are unclear. The National Strategy on Climate Change 2007 and Special Program on Climate Change 2009-2012 (Estados Unidos Mexicanos (EUM) 2009, Secretaria de Medio Amiente y Recursos Naturales (SEMARNAT) and Instituto Nacional de Ecologia (INE) 2009) recognize the magnitude of the problems and include a range of substantial mitigation measures, which are incorporated in the 2007-2012 National Development Plan, as well as some adaptation actions. Modest renewable power increases are proposed, including hydropower and biofuel expansion. Large vegetation and land-use targets are included, involving forest restoration and expansion and enhancing protected areas. The proposed adaptation measures for water, although lacking targets, are focused on better management 
of surface and ground water sources, including watershed restoration. In Mexico's $4^{\text {th }}$ National Communication to the UNFCCC, reported implementation of adaptation measures lags behind mitigation action (SEMARNAT and INE 2009). The multi-stakeholder and expert-based Consultative Council on Climate Change and the ministerial Intersecretarial Commission on Climate Change provide a strong institutional structure for policy development and implementation, although mechanisms to translate this federal policy into state-level implementation are not evident.

\section{South Africa}

South Africa has a formal climate change policy that is out of date and incapable of supporting integrated management of climate change and water resources and ecosystems. The National Climate Change Response Strategy (Government of South Africa 2004) mainly proposes to study the problem. A new policy was supposed to be finalized in 2010. More recent government statements propose a range of measures that involve water-intensive carbon mitigation options, including carbon capture and storage, and biofuel production. South Africa is already water scarce, and is likely to experience even less runoff over large parts of the country with climate change. Surprisingly, their long history of regulating land uses that reduce stream flow has not been translated into climate adaptation policies. More than the other countries assessed here, South Africa appears to afford little political importance to climate change, with responsibility resting with the Minister for Environmental Affairs, informed by a Council on Climate Change (advisory) Committee and implemented in part through a Government Climate Change (inter-departmental) Committee.

\section{Tanzania}

On paper, Tanzania has identified priorities for action and integrative mechanisms, including for water, but further work is needed to assess whether their adaptation program represents short-lived and donor-driven action or whether it is a genuine sign of government commitment to addressing the challenges of climate change. Tanzania's National Adaptation Program of Action (United Republic of Tanzania (URT) 2007) takes a comprehensive overview of their climate change challenges, appears to have been developed with extensive consultation, and identifies a modest number of priorities for practical action, many of them water related. Responsibility for climate change rests with the Vice-President and this is supported by a National Climate Change Committee. Although these measures appear positive, the government's website makes limited reference to climate change and does not provide access to key policy documents, nor are climate mitigation measures discussed.

\section{Commonalities among developing jurisdictions}

The developing country jurisdictions have a number of commonalities, notably, their climate policies generally integrate mitigation and adaptation measures. They have policies in favor of low carbon but water-intensive energy technologies, with the richer developing countries adopting substantial targets that will have perverse impacts on water resources and ecosystems. All of these countries have measures for substantial afforestation that do not consider the impacts on green water use and reduction of surface water inflows. Basically, the conflicts between carbon sequestration and energy generation vs. water resources and ecosystems have not been recognized or managed. A diverse array of water-related climate adaptation measures are proposed, ranging from a few measures in Brazil to a broad range in China, and these include significant infrastructure and supply-led approaches through to those that focus on restoration of the natural sources of water. No and low regrets measures have largely been overlooked in these nations, such as conservation of wetlands as carbon sinks, and restoration of floodplains to manage floods. Most of these countries have intra-governmental and multi-stakeholder coordination mechanisms, but there are few inter-governmental mechanisms to engage sub-national governments. An important difference is that many of these nations use 5-year plans as cyclical policy mechanisms, but all lack climate change-focused legislation and most do not have independent review mechanisms.

\section{DISCUSSION OF COMMON ELEMENTS}

Assessment of these national policies demonstrates how poorly governmental decision makers understand that many energy generation and carbon sequestration technologies largely depend on 
adequate water supplies. This is a major flaw in the climate and energy policies examined that needs to be addressed if objectives are to be met in all relevant sectors (e.g., biodiversity, water, energy, and climate).

\section{Currency of key policies}

It is apparent that many of the sectoral policies assessed were adopted before the magnitude of the challenges from climate change were understood. In particular, many nations' biodiversity policies appear to be out of date, and to a lesser extent, their water policies as well (Table 1). Many of the environmental and water policies are largely predicated on the assumption of climatic and hydrological stationarity (apart from those of Australia and the UK) (Milly et al. 2008) and are unfit for this era. Many of the policies that do cite climate change recommend further monitoring and research rather than proposing more meaningful actions (Table 3). There are some indications that governments are beginning to revise out-of-date policies, as with South Africa and Australia's energy policies. Energy and climate policies tend to be those that are most recent (Table 1). The more integrated approaches, such as those of China and the EU, appear to rely in part on cyclical processes for policy renewal, such as 5-year plans, consistent with the findings of Dovers (2005) on better practices for sustainability institutions.

\section{Technologies and measures deployed}

All jurisdictions have adopted carbon sequestration and energy generation technologies that do not consider and may substantially impact on green and blue water resources. Biofuel and forestry expansion are promoted by nearly all countries. Although hydropower is favored by most, the magnitude of the expansion planned in Brazil, China, and India will have significant impacts on their freshwater environments and resources (Pittock 2010b). Only India explicitly considered pumped-storage hydropower (Government of India 2008), which may be a lower impact alternative. Expansion of nuclear power is underway in many jurisdictions, raising questions as to the reliability of supplies of cooling water (Hightower and Pierce 2008). Measures for carbon capture and storage in developed countries appeared oblivious to the additional water requirements of these plants
(NETL 2008, Smart and Aspinall 2009). Surprisingly, many synergistic interventions are not specifically endorsed, including such low regrets measures as wetlands conservation, energy efficiency in water systems, and power generation from sewerage (EA 2009).

Although a broad spectrum of water-related adaptations are favored by the countries, the degree of commitment is much less convincing in most cases compared with mitigation technologies in terms of specificity, funding, and targets (Table 3 ). Some states appear to favor high-impact infrastructure measures such as long-distance interbasin water transfers, whereas others tend toward restoring the environment as a source of water. Synergies in adaptation were also neglected, such as restoration of floodplains to better manage extreme floods (Opperman et al. 2009).

\section{Policy integration}

It is apparent that relatively few of the energy and climate change policies have considered sustaining freshwater ecosystems services, even where there is a long history of water scarcity and conflict, as in Australia (Tables 2 and 3). Those climate and energy policies that do cite freshwater resources do this in terms of greater exploitation for energy generation. Brazil and China make the extra commitments to develop hydropower in a manner that minimizes impacts on people and the environment (Government of China 2007b), yet implementing these commitments may require a great improvement in standards, accountability and enforcement measures.

Surprisingly, a number of countries either have no detailed overarching climate policy, as with Australia (there is relatively little substance behind the policy outline cited in Newell et al. (2011) compared with the UK), or overlook key aspects of a coherent climate change strategy, such as Brazil's incomplete adaptation measures (Government of Brazil 2008). It would appear that the more integrated policies, such as those of China and the EU, emerge from jurisdictions with strong central leadership, cyclical policy processes, and/or robust accountability mechanisms (such as the EU processes for enforcing directives). A number of jurisdictions show a growing tendency to explicitly integrate climate and energy policies, including the EU, Australia, and South Africa. However, the links 
to sustainable freshwater ecosystem services appear very poorly understood. In contrast, a number of non-government organizations have gone a step further with broad-scale modeling that seeks to explicitly consider trade-offs among social wellbeing, the environment, and access to energy, such as the assessment of different global energy options in Climate solutions (WWF 2007).

\section{Leadership}

The degree of engagement of senior national or EU leaders in climate change policy development appears to correlate to the extent to which these policies are comprehensive, integrated, and target driven. The better policies appear to have been developed under the auspices of senior leaders and ministers in multi-sector processes, such as those of China (through their NDRC) and the EU. In contrast, nations where the senior leadership is not engaged, as in South Africa, appear to be languishing. In most countries, environmental ministries are relatively junior government agencies, and their assignment in the lead role for coordinating whole-of-government implementation of national climate change policies, as with Brazil and India, raises questions as to how effectively they will be implemented. Australia has a unique institutional arrangement with a (new and) separate Department of Climate Change; only time will tell whether this will lead to a more effective national focus on climate change responses, or whether it will exacerbate sectoral silos within government.

\section{Independent review and accountability mechanisms}

Few of the jurisdictions examined had independent review institutions capable of providing more objective advice to government on these environment and sustainable development policies, which could be a key avenue for identifying and addressing perverse outcomes or synergies. In this role, Brazil has a sustainable development commission, whereas the UK's is being abolished in 2011 (Prakash 2011), and the European Commission (often with third-party engagement) plays a strong enforcement role with the EU Member States. Australia and the EU have "stateof-the-environment" reporting processes.

\section{Further research}

This initial examination of a broad sample of climate change policies from nine governments has identified a number of issues, trends, and opportunities that should be subject to more detailed analysis for policy development in specific jurisdictions. There is potential for this overview to be followed by theoretical exploration and testing of policy and institutional design. Building on the work of de Fraiture et al. (2008) for biofuel production, further assessment could seek to quantify the water use implications of a range of climate change response measures. Specific institutional elements that could be further examined include: quantifying the costs and benefits of the sectoral vs. integrated approaches in responding to climate change; assessment of how these policy settings are implemented in practice (a new institutionalism approach (Young 1999)); factors that favored the establishment, maintenance, and effectiveness of the national integrative mechanisms identified in this research; and the effectiveness of the separate climate change ministries in Australia and the United Kingdom (combining climate change and energy) vs. other models of administering national climate change responses.

\section{CONCLUSION}

Regardless of climate change, pollution and the growth in demand for water globally are diminishing biodiversity and the quality of life for a vast number of people. Climate change mitigation is an important objective and there are a variety of alternative responses that could achieve reductions in greenhouse gas emissions. Many choices, such as greater use of energy technologies like hydropower and biofuels, will consume significantly more water and impact on the provision of other freshwater ecosystem services. Similarly, climate change adaptation measures may represent maladaptation, in having negative impacts on other sectors, or be synergistic with other sectoral goals. This paper outlines evidence of perverse impacts from poorly integrated national and international climate and energy policies on other freshwater ecosystem services. The paper also identifies opportunities for synergies among water, energy, and climate change policies that few governments have identified or prioritized, such as carbon sequestration through wetlands conservation, 
energy generation from sewage, energy efficiency in water services, and restoration of floodplains.

A number of factors are identified as promoting more sustainable cross-sector policy development, including engagement of high-level leaders; multisector forums for enhanced policy development; iterative policies to build on experience of previous periods; and independent review and enforcement mechanisms. Governments and societies need to apply these lessons to better integrate their sectoral policies for climate change, energy, water, and other relevant sectors to benefit people and the environment. This overview of the policy settings from a broad range of countries could be followed by: (i) more detailed theoretical exploration and testing, in terms of policy and institutional design, and (ii) more detailed analysis for policy development in specific jurisdictions.

Responses to this article can be read online at: http://www.ecologyandsociety.org/voll6/iss2/art25/ responses/

\section{Acknowledgments:}

I thank Eugenio Barrios and Glauco de Freitas for advice on relevant national policies, and support from the WWF network in undertaking elements of this research. Comments on the draft paper from Stephen Dovers, Karen Hussey, the editor, and two anonymous reviewers were greatly appreciated.

\section{LITERATURE CITED}

Amarasinghe, U. A., T. Shah, and P. G. McCornick. 2008. Seeking calm water: exploring policy options for India's water future. Natural Resources Forum 32(4):305-315.

Bates, B. C., Z. W. Kundzewicz, S. Wu, and J. P. Palutikof, editors. 2008. Climate change and water. Technical Paper of the Intergovernmental Panel on Climate Change (IPCC). IPCC Secretariat, Geneva, Switzerland.

Butler, D., and F. A. Memon. 2006. Water demand management. IWA Publishing, London, UK.
Calder, I. R. 2007. Forests and water-ensuring forest benefits outweigh water costs. Forest Ecology and Management 251(1-2):110-120.

Calder, I. R., and M. D. Newson. 1979. Land-use and upland water resources in Britain: a strategic look. Journal of the American Water Resources Association 15(6): 1628-1639.

Commonwealth of Australia, Government of New South Wales, Government of Victoria, Government of Queensland, Government of South Australia, Government of the Australian Capital Territory and Government of the Northern Territory. 2004. Intergovernmental Agreement on a National Water Initiative. Council of Australian Governments. [online] URL: http://www.nwc.gov.au/www/html/117national-water-initiative.asp.

Commonwealth of Australia, The State of New South Wales, The State of Victoria, The State of Queensland, The State of South Australia and The Australian Capital Territory. 2008. Agreement on Murray-Darling Basin Reform. Council of Australian Governments. [online] URL: http://www .coag.gov.au/coag meeting outcomes/2008-07-03/ docs/Murray Darling IGA.pdf.

Comprehensive Assessment of Water Management in Agriculture (CAoWMiA). 2007. Water for food, water for life. A comprehensive assessment of water management in agriculture. Earthscan and International Water Management Institute, London, UK and Colombo, Sri Lanka.

de Fraiture, C., M. Giordano, and Y. Liao. 2008. Biofuels and implications for agricultural water use: blue impacts of green energy. Water Policy $\mathbf{1 0}$ (S1):67-81.

Department of Climate Change and Energy Efficiency (DCCEE). 2010. Design of the carbon farming initiative. Consultation paper. DCCEE, Canberra, Australia. [online] URL: http://www.clim atechange.gov.au/government/submissions/carbonfarming-initiative.aspx.

Department of Energy (DoE). 2008. Concentrating solar power commercial application study: reducing water consumption of concentrating solar power electricity generation. Report to Congress. DoE, Golden, Colorado, USA. [online] URL: http: //www.nrel.gov/csp/pdfs/csp water study.pdf. 
Dovers, S. 2005. Environment and sustainability policy: creation, implementation, evaluation. Federation Press, Annandale, New South Wales, Australia.

Dovers, S. R., and A. A. Hezri. 2010. Institutions and policy processes: the means to the ends of adaptation. Wiley Interdisciplinary Reviews: Climate Change 1(2):212-231.

Environment Agency. 2009. Water for people and the environment. Water resources strategy for England and Wales. Environment Agency, Bristol, UK. [online] URL: www.environment-agency.gov. uk.

Estados Unidos Mexicanos (EUM). 2009. Programa Especial de Cambio Climático 20082012. Poder Ejecutivo Federal, EUM, Mexico City, Mexico. (In Spanish) [online] URL: http://www.ca mbioclimatico.gob.mx/images/stories/PDF/pecc capitulos. pdf.

European Commission. 2001. Directive 2000/60/ EC of the European Parliament and of the Council of 23 October 2000 establishing a framework for Community action in the field of water policy. European Commission, Brussels, Belgium. [online] URL: http://europa.eu/legislation_summaries/agriculture/ environment/128002b en.htm.

European Commission. 2007. Adapting to climate change in Europe - options for EU action. Green paper from the Commission to the Council, the European Parliament, the European Economic and Social Committee and the Committee of the Regions. COM(2007) 354 final, European Commission, Brussels, Belgium. [online] URL: htt p://eur-lex.europa.eu/LexUriServ/LexUriServ.do?uri= COM:2007:0354:FIN:EN:PDF.

European Commission 2008. Combating climate change. The EU leads the way. European Commission, Brussels, Belgium. [online] URL: htt $\mathrm{p}: / /$ ec.europa.eu/publications/booklets/move/75/en. pdf.

Falkenmark, M., and D. Molden. 2008. Wake up to realities of river basin closure. Water Resources Development 24(2):201-215.

Garnaut, R. 2008. The Garnaut climate change review: final report. Cambridge University Press, Melbourne, Australia. [online] URL: http://www.g arnautreview.org.au/index.htm.
Gerbens-Leenes, P. W., A. Y. Hoekstra, and T. H. van der Meer. 2008. Water footprint of bio-energy and other primary energy carriers. UNESCO-IHE Institute for Water Education, Delft, The Netherlands. [online] URL: http://www.waterfootp rint.org/Reports/Report29-WaterFootprintBioenergy. pdf.

Gleick, P. H. 2002. Water management: Soft water paths. Nature 418(6896):373-373.

Government of Australia. 2008. White paper. Carbon pollution reduction scheme: Australia's low pollution future. Department of Climate Change, Canberra, Australia. [online] URL: http://www.clim atechange.gov.au/whitepaper/index.html.

Government of Brazil. 2008. Executive summary. National plan on climate change. Decree No. 6263 of 21 November 2007 (English version). Interministerial Committee on Climate Change, Government of Brazil, Brasilia, Brazil. [online] URL: http://www.mma.gov.br/estruturas/imprensa/ arquivos/96 11122008040728.pdf.

Government of China. 2007. China's national climate change programme. (English version). National Reform and Development Commission, Beijing, People's Republic of China. [online] URL: http://www.ccchina.gov.cn/WebSite/CCChina/UpFile/ File188.pdf.

Government of India. 1998. Policy on hydro power development. Government of India, Dehli, India. [online] URL: http://www.nhpcindia.com/writereaddata/ English/PDF/hydro-policy.pdf.

Government of India. 2008. National action plan on climate change. Prime Minister's Council on Climate Change. Government of India, Dehli, India. [online] URL: http://pmindia.nic.in/Pg01-52.pdf.

Government of South Africa (GoSA). 2004. National climate change response strategy. Government of South Africa, Pretoria, South Africa. [online] URL: www.environment.gov.za/C limateChange2005/climateChangeResopnseStrategu/

Gujja, B., S. Dalai, H. Shaik, and V. Goud. 2009. Adapting to climate change in the Godavari River basin of India by restoring traditional water storage systems. Climate and Development 1(3):229-240. 
Gujja, B., S. Ramakrishna, V. Goud, and Sivaramakrishna, editors. 2006. Perspectives on Polavaram. A major irrigation project on the Godavari. Academic Foundation, New Dehli, India.

Gupta, S. K., and R. D. Deshpande. 2004. Water for India in 2050: first-order assessment of available options. Current Science 86(9):1216-1224.

Herron, N., R. Davis, and R. Jones. 2002. The effects of large-scale afforestation and climate change on water allocation in the Macquarie River catchment, NSW, Australia. Journal of Environmental Management 65(4):369-381.

Hightower, M., and S. A. Pierce. 2008. The energy challenge. Nature 452(7185):285-286.

HM Government. 2008a. Adapting to climate change in England. A framework for action. Department for Environment, Food and Rural Affairs, London, UK. [online] URL: www.defra.go v.uk.

HM Government. 2008b. Climate Change Act 2008. The Stationery Office Limited, London, UK. [online] URL: http://www.opsi.gov.uk/acts/acts2008/ pdf/ukpga 20080027 en.pdf.

Hodson, D., and I. Maher. 2001. The open method as a new mode of governance: the case of soft economic policy co-ordination. Journal of Common Market Studies 39(4):719-746.

Hutson, S. S., N. L. Barber, J. F. Kenny, K. S. Linsey, D. S. Lumia, and M. A. Maupin. 2004. Estimated use of water in the United States in 2000. U.S. Geological Survey, Reston, USA. [online] URL: http://pubs.usgs.gov/circ/2004/circ1268/pdf/ circular1268.pdf.

Inhaber, H. 2004. Water use in renewable and conventional electricity production. Energy Sources 26(3):309-322.

Johnson, K. M., editor. 2009. Dr Kristina M. Johnson, Under Secretary of Energy, U.S. Department of Energy before the Committee on Science and Technology Subcommittee on Energy and Environment, U.S. House of Representatives, 9 July 2009 Committee on Science and Technology, US House of Representatives, Washington, D.C., USA.
Kabat, P., and H. Schaik. 2003. Climate changes the water rules: how water managers can cope with today's climate variability and tomorrow's climate change. Dialogue on Water and Climate, Delft, The Netherlands. [online] URL: http://www.waterandcl imate.org/?id=CPWCresources340.

Laffan, B. 2001. The European Union polity: a union of regulative, normative and cognitive pillars. Journal of European Public Policy 8(5):709-727.

Millennium Ecosystem Assessment (MEA). 2005a. Ecosystems and human well-being: synthesis. Island Press, Washington, D.C., USA.

Millennium Ecosystem Assessment (MEA). 2005b. Ecosystems and human well-being: wetlands and water synthesis. World Resources Institute, Washington, D.C., USA.

Milly, P. C. D., J. Betancourt, M. Falkenmark, R. M. Hirsch, Z. W. Kundzewicz, D. P. Lettenmaier, and R. J. Stouffer. 2008. Stationarity is dead: whither water management? Science 319:573-574.

Ministry of Water Resources (MWR). 2002. Nationalwater policy. Ministry of Water Resources, Government of India, New Dehli, India. [online] URL: www.rajirrigation.gov.in/5nwp.htm.

Ministry of Water Resources (MWR). 2009. National water mission under national action plan on climate change: comprehensive mission document. Volume I, April 2009. Ministry of Water Resources, Government of India, New Delhi, India. [online] URL: http://mowr.gov.in/writereaddata/ linkimages/MissionDocument8395131900.pdf.

National Energy Technology Laboratory (NETL). 2008. Estimating freshwater needs to meet future thermoelectric generation requirements. 2008 update. DOE/NETL-400/2008/1339. September 30 2008. U.S. Department of Energy, National Energy Technology Laboratory, Pittsburgh, Pennsylvania, USA. [online] URL: www.netl.doe.gov.

National Water Development Agency (NWDA). 2008. National Perspective Plan (NPP). National Water Development Agency, Government of India, Dehli, India. [online] URL: www.nwda.gov.in/psub linkdetails.asp?sublinkid=48andlanded=1.

Newell, B., D. Marsh, and D. Sharma. 2011. Climate-energy-water: the need for integrated 
adaptation and mitigation policies in the Australian electricity sector. Ecology and Society 16(2):15. [online] URL: http://www.ecologyandsociety.org/vol16/ $\underline{\text { iss } 2 / \operatorname{art} 15}$

Opperman, J. J., G. E. Galloway, J. Fargione, J. F. Mount, B. D. Richter, and S. Secchi. 2009. Sustainable floodplains through large-scale reconnection to rivers. Science 326(5959):4871488 .

Pittock, A. B. 2009a. Climate change: the science, impacts and solutions. Second edition. CSIRO Publishing, Collingwood, Victoria, Australia.

Pittock, J. 2009b. Lessons for climate change adaptation from better management of rivers. Climate and Development 1(3):194-211.

Pittock, J. 2010a. A pale reflection of political reality: integration of global climate, wetland, and biodiversity agreements. Climate Law 1(3):343373.

Pittock, J. 2010b. Better management of hydropower in an era of climate change. Water Alternatives 3(2):444-452.

Pittock, J., and B. A. Lankford. 2010. Environmental water requirements: demand management in an era of water scarcity, Journal of Integrative Environmental Sciences 7(1):75-93.

Prakash, N. 2011. Axeing of UK sustainability watchdog leaves gap in scrutiny, MPs warn. The Guardian January 2011. [online] URL: http://www. guardian.co.uk/environment/2011/jan/10/sustainabledevelopment-commission-scrutiny-gap.

Proust, K., S. Dovers, B. Foran, B. Newell, W. Steffan, and P. Troy. 2007. Climate, energy and water: accounting for the links. Land and Water Australia, Canberra, Australia. [online] URL: http: //lwa.gov.au/products/er071256.

Ramsar Secretariat. 2009. Convention on Wetlands of International Importance especially as Waterfowl Habitat. Ramsar (Iran), 2 February 1971. As amended by the Paris Protocol, 3 December 1982, and Regina Amendments, 28 May 1987. UN Treaty Series No. 14583. Ramsar Secretariat, Gland, Switzerland. [online] URL: http://www.ram sar.org/cda/ramsar/display/main/main.jsp?zn= ramsarandcp $=1-31-38 \quad 4000 \quad 0$.
Reffold, E., F. Leighton, F. Choudhury, and P. S. Rayner. 2008. Greenhouse gas emissions of water supply and demand management options. Science report - SC070010, Environment Agency, London, UK. [online] URL: www.environment-agency.gov. uk.

Rockström, J., and L. Gordon. 2001. Assessment of green water flows to sustain major biomes of the world: implications for future ecohydrological landscape management. Physics and Chemistry of the Earth, Part B: Hydrology, Oceans and Atmosphere 26(11-12): 843-851.

Rockström, J., L. Gordon, C. Folke, M. Falkenmark, and M. Engwall. 1999. Linkages among water vapor flows, food production, and terrestrial ecosystem services, Conservation Ecology 3(2): 5. [online] http://www.ecologyandsociety.org/vol3/iss2/art5/.

Rockström, J., W. Steffen, K. Noone, A. Persson, F. S. Chapin, E. F. Lambin, T. M. Lenton, M. Scheffer, C. Folke, H. J. Schellnhuber, B. Nykvist, C. A. de Wit, T. Hughes, S. van der Leeuw, H. Rodhe, S. Sörlin, P. K. Snyder, R. Costanza, U. Svedin, M. Falkenmark, L. Karlberg, R. W. Corell, V. J. Fabry, J. Hansen, B. Walker, D. Liverman, K. Richardson, P. Crutzen, and J. A. Foley. 2009. A safe operating space for humanity, Nature 461:472475.

Ross, A., and S. Dovers. 2008. Making the harder yards: environmental policy integration in Australia. Australian Journal of Public Administration 67(3):245-260.

Schout, A., and A. Jordan. 2005. Coordinated European governance: self-organizing or centrally steered? Public Administration 83(1):201-220.

Secretaria de Medio Amiente y Recursos Naturales (SEMARNAT) and Instituto Nacional de Ecologia (INE). 2009. Mexico cuarta comunicacion nacional ante la convencion marco de las naciones unidas sobre el cambio climatico. Secretaria de Medio Amiente y Recursos Naturales and Instituto Nacional de Ecologia, Mexico City, Mexico. [Spanish, English summary.] [online] URL: http:// unfccc.int/resource/docs/natc/mexnc4s.pdf. 
Smart, A., and A. Aspinall. 2009. Water and the electricity generation industry. Implications of use. National Water Commission, Canberra, Australia. [online] URL: www.nwc.gov.au.

Stillwell, A. S., C. W. King, M. E. Webber, I. J. Duncan, and A. Hardberger. 2011. The energywater nexus in Texas. Ecology and Society 16(1):2. [online] URL: http://www.ecologyandsociety.org/voll6/ iss1/art2.

United Nations (UN). 1992a. Convention on biological diversity (with annexes). Concluded at Rio de Janerio on 5 June 1992. United Nations, New York, New York, USA.

United Nations (UN). 1992b. United Nations Framework Convention on Climate Change. United Nations, New York, New York, USA.

United Nations General Assembly (UNGA). 2000. United Nations Millennium Declaration. Resolution adopted by the General Assembly 55/2. New York, United Nations.

United Republic of Tanzania(URT). 2007. National adaptation programme of action (NAPA). Vice President's Office, Division of Environment, January 2007. United Nations Framework Convention on Climate Change, Bonn, Germany. [online] URL: http://unfccc.int/resource/docs/napa/ tza01.pdf.

van Dijk, A. I. J. M., and R. J. Keenan. 2007. Planted forests and water in perspective. Forest Ecology and Management 251(1-2):1-9.

van Nood, M. 2008. Climate change adaptationpreparations for a framework at EU level. Water and Climate Day 2, 21 August 2008. Stockholm World Water Week, Stockholm, Sweden.

World Water Assessment Programme (WWAP). 2009. The United Nations world water development report 3: water in a changing world. UNESCO Publishing, Paris, France and Earthscan, London, UK. [online] URL: http://www.unesco.org/water/w wap/wwdr/wwdr3/.

World Wildlife Fund (WWF). 2004. Repowering hydroelectric utility plants as an environmentally sustainable alternative to increasing energy supply in Brazil. WWF Brazil, Brasilia, Brazil. [online] URL: http://assets.panda.org/downloads/ brazilupgradinghydropowerreport.pdf (accessed 2 September 2010).

World Wildlife Fund (WWF). 2007. Climate solutions. WWF's vision for 2050. WWF International, Gland, Switzerland.

Young, O. R., editor. 1999. The effectiveness of international environmental regiemes: causal connections and behavioral mechanisms. The MIT Press, Cambridge, Massachusetts, USA.

Young, O. R. 2002. The institutional dimensions of environmental change: fit, interplay and scale. MIT Press, Boston, Massachusetts, USA. 